\begin{tabular}{cc|c}
\hline Tar. Bil. Der. & Journal of Agricultural Sciences \\
& $\begin{array}{c}\text { Dergi web sayfası: } \\
\text { www.agri.ankara.edu.tr/dergi }\end{array}$ & Journal homepage: \\
& www.agri.ankara.edu.tr/journal
\end{tabular}

\title{
Drainage Water Salt Load Variations Related to the Salinity and Leaching Ratios of Irrigation Water
}

\author{
Engin YURTSEVEN ${ }^{a}$, Müslime Sevba ÇOLAK ${ }^{a}$, Ahmet ÖZTÜRK ${ }^{a}$, Hasan Sabri ÖZTÜRK ${ }^{b}$ \\ aAnkara University, Faculty of Agriculture, Department of Agricultural Structures and Irrigation, Ankara, TURKEY

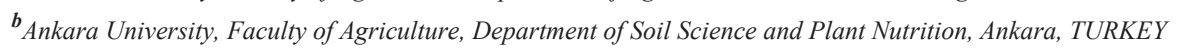

\section{ARTICLE INFO}

Research Article

DOI: 10.15832 /ankutbd.456667

Corresponding Author: Engin YURTSEVEN, E-mail: yurtsev@ankara.edu.tr, Tel: +90 (532) 5649144

Received: 16 March 2017, Received in Revised Form: 18 July 2017, Accepted: 17 September 2017

\begin{abstract}
Solubility of salts and leaching fractions have different effects on drainage water quality. Knowing the quality of drainage water is extremely important in terms of environmental factors and quality of water resources for the reason that this water is transferred to various sources.

In this study, were studied the changes of drainage water salinity and salt load under lyzimeter (soil columns) conditions using different irrigation water salinity and with different leaching fractions. The study was carried out with sunflower in PVC soil columns with $40 \mathrm{~cm}$ diameter and $115 \mathrm{~cm}$ length with 3 different irrigations and 5 irrigation waters with different salinity level. The three irrigation treatments were $75 \%, 115 \%$ and $135 \%$ of the required irrigation water. The irrigation water salinities were $0.25 \mathrm{dS} \mathrm{m}^{-1}$ as control treatment, 1.5 and $3.0 \mathrm{dS} \mathrm{m}^{-1}$ with $\mathrm{NaCl}+\mathrm{CaCl}_{2}$ salts and 1.5 and $3.0 \mathrm{dS} \mathrm{m}^{-1}$ with $\mathrm{NaCl}+\mathrm{CaSO}_{4}$ salts as saline treatments.

In this study investigated drainage water quality variations and salt load with irrigation water and some individual ions load and their leaching by drainage water as well. Drainage water salinities variated with both irrigation water salinity and leaching fractions. It was higher under the effect of soluble salts and with the $15 \%$ leaching fraction. However, salt load was higher at $35 \%$ leaching fractions level. When discuss the individual ions; while $\mathrm{Cl}^{-}$, $\left(\mathrm{CO}_{3}^{-2}+\mathrm{HCO}_{3}^{-}\right)$and $\mathrm{Ca}^{+2}$ were accumulated in the soil profile, $\mathrm{SO}_{4}^{-2}, \mathrm{Na}^{+}$ve $\mathrm{Mg}^{+2}$ were leaced from the profile, and all these ions variated by interaction for irrigation waters, and by leaching fractions for the drainage water.
\end{abstract}

Keywords: Irrigation water quality; Drainage water quality management; Solubility of salts; Leaching fraction; Salt load; Lysimeter experiment

(C) Ankara Üniversitesi Ziraat Fakültesi

\section{Introduction}

In most of the world's irrigated lands, there occur salinity and drainage problems due to irrigations and today it is known that irrigation is almost impossible without adequate drainage. Drainage is also significant in controlling salinity problems. The fact that accumulated salts can only be leached from the profile via leaching water, requires the absence of drainage problems in the area. Drainage water returns to natural resources or gets used in irrigating lower plains. Therefore, the quality of drainage water become important for water resources, for irrigation practices and also for the environmental point of view. 
Salts affect soil water salinity according to their solubility. High solubility salts are highly concentrated salts that are easily soluble and harm the growth of plants. Conversely, low solubility salts are ones that never reach a high enough concentration to harm the plants (Ayers \& Westcot 1988; van Hoorn \& van Alpen 1988).

The estimation of drainage water below root zone is essential for evaluating risks of soil salinity in dry areas, developing irrigation management and tracking damage of agricultural chemicals in the ecosystem (Bond 1998; Walker et al 2002). The quality of drainage water reflects the quality of water table and the components of the drained water. Drainage water in irrigated dry places contains salts such as $\mathrm{NaCl}$ and $\mathrm{CaSO}_{4}$ and may include elements such as Se, B and Ar. The core of sustainable irrigated agriculture is plant root zone salinity management and the requirement for controlled drainage implements to this end (Ayars et al 2006).

Regarding sustainable irrigated agriculture, leaching is a necessary procedure in order to avoid the accumulation of soluble salts in the root zone. The salinity of drainage water is increased with the leaching of salts from the root zone. Therefore, despite an increase in irrigation efficiency, that is to say, a decrease in leaching ratio might mean an increase in below root zone salinity concentration, it would also mean a decrease in drainage water salt load (Oster \& Rhoades 1978). Northey et al (2006) have stated that there is a relation between the changes in salinity of the water table and depth. Generally, as depth increases, salinity in irrigated areas increases.

The increase of world's population and expansion of irrigated areas on one hand, and global warming and decrease of clean water resources on the other, make it unfortunately obligatory for poor quality water to be used in certain irrigation areas (Şener 1993). In the long run, $50 \%$ of the irrigation water needs will be met with rotational drainage water usage (Rhoades 1983). In Egypt, drainage water is diluted before usage. Therefore, additional water resources are created and as inhomogeneous water distribution becomes balanced, irrigation efficiency rises significantly (Wolters \& Bos 1990). In a study done in Konya, where irrigation agriculture is common, $22 \%$ of farmers use irrigation water from drainage canals (Çiftçi et al 1995). Heng et al (1991) have carried out an experiment to determine the leaching losses of $\mathrm{Cl}^{-}, \mathrm{SO}_{4}^{-2}, \mathrm{NO}_{3}^{-1}, \mathrm{~K}^{+}, \mathrm{Mg}^{+2}$, $\mathrm{Ca}^{+2}$ and $\mathrm{Na}^{+}$, and found that $\mathrm{Cl}^{-}$was the dominant anion in the drainage water, with losses total concentration of $100 \mathrm{~kg} \mathrm{ha}^{-1}$ per year. The leaching loss of $\mathrm{S}_{4}$ was concentration of $13 \mathrm{~kg} \mathrm{~S} \mathrm{ha}^{-1}$ per year from the paddock fertilized with superphosphate compared with $3 \mathrm{~kg} \mathrm{ha}^{-1}$ per year from the elemental S-fertilized paddock.

Irrigation with saline water and applying leaching fractions affected the mass balance of soil salinity constituents. Yurtseven at al (2014) stated that increasing leaching fractions in relation with the irrigation water salinity, caused to change soil $\mathrm{Cl}^{-}, \mathrm{SO}_{4}^{-2}, \mathrm{HCO}_{3}^{-}, \mathrm{Ca}^{+2}, \mathrm{Mg}^{+2}$, and $\mathrm{Na}^{+}$balances; while $\mathrm{Cl}^{-}, \mathrm{SO}_{4}^{-2}, \mathrm{Mg}^{+2}$ and $\mathrm{Na}^{+}$washed out with leaching water, $\mathrm{HCO}_{3}^{-}$and $\mathrm{Ca}^{+2}$ accumulated in $\mathrm{SCL}$ soil profile.

In this study, the leaching tendency of individual ions and salt loads have been analyzed in regards to irrigation water containing different solubility salts as well as drainage water salinity under varying leaching fractions, in homogeneous soil in lysimeters.

\section{Material and Methods}

The experiment was held in Ankara University Agricultural Faculty at Dışkapı Campus, as an outdoors cultivation between June $9^{\text {th }}$-September $16^{\text {th }} 2015$ with sunflower. Lysimeters were set up with corruge PVC tubes of $40 \mathrm{~cm}$ diameter and $115 \mathrm{~cm}$ height. The soil, was provided from the top 20-60 $\mathrm{cm}$ profile of the surrounding cultivated area and sieved and put into lysimeters in equal amounts according to their bulk density. The soil used was sandy-loam and its bulk density $1.35 \mathrm{~g} \mathrm{~cm}^{-3}, \mathrm{pH} 8.03$, $\mathrm{EC}_{\mathrm{p}}$ (at 1:2 saturation) $1.92 \mathrm{dS} \mathrm{m}^{-1}$, field capacity $25.1 \%$, and wilting point $15.2 \%$. The sunflower 
used was "Meriç", an original variety from Thrace Agricultural Research Institute of Turkey.

As treatments 5 salinity levels (S) and 3 irrigation amounts (L) have been used in a total of 45 lysimeters. Experiments were done as a factorial experiment in fully randomized design with 3 replications. Irrigations were done with water containing at various rates of $\mathrm{NaCl}, \mathrm{CaCl}_{2}$ and $\mathrm{CaSO}_{4} \cdot 2 \mathrm{H}_{2} \mathrm{O}$ salts. Irrigation water salinity levels were $\mathrm{S}_{1}=$ top water $\left(0.25 \mathrm{dS} \mathrm{m}^{-1}\right), \mathrm{S}_{2}=1.5 \mathrm{dS} \mathrm{m}^{-1} \mathrm{NaCl}+\mathrm{CaCl}_{2}, \mathrm{~S}_{3}=3 \mathrm{dS}$ $\mathrm{m}^{-1} \mathrm{NaCl}+\mathrm{CaCl}_{2}, \mathrm{~S}_{4}=1.5 \mathrm{dS} \mathrm{m}{ }^{-1} \mathrm{NaCl}+\mathrm{CaSO}_{4} \cdot 2 \mathrm{H}_{2} \mathrm{O}$ and $\mathrm{S}_{5}=3 \mathrm{dS} \mathrm{m}^{-1} \mathrm{NaCl}+\mathrm{CaSO}_{4} \cdot 2 \mathrm{H}_{2} \mathrm{O}$. Irrigation water was applied with leaching fractions as $115 \%$ $\left(\mathrm{L}_{15}\right)$ and $135 \%\left(\mathrm{~L}_{35}\right)$. Field experiments also had a treatment of limited irrigation, i.e. $75 \%$ of the required amount $\left(\mathrm{L}_{075}\right)$ but, this treatment was not included to this drainage water quality evaluation since it didn't produce drainage water. Drainage waters were collected from the leaching treatments of $\mathrm{L}_{15}$ and $\mathrm{L}_{35}$.

This experiment implemented 8 irrigations during growing season and these were dated according to TDR (Trace) and gravimetric soil water analyses, considering of $40 \%$ usage of available soil water. After each irrigation, drainage water was collected from plastic cups previously put at the bottom of soil columns. EC measurements were taken with ECmeter (YSI-3000) according to USSL (1954). The anion and cation analysis were taken via ion chromatography (DIONEX IC-1600) apparatus according to Anonymous (1993).

Salt load values of drainage waters were calculated by multiplying the total drainage volume $(\mathrm{mm})$ and drainage water salinity $\left(\mathrm{EC}, \mathrm{dS} \mathrm{m}^{-1}\right)$ and denoted as ECmm (van Hoorn \& van Alpen 1988). Salt load values regarding ion concentrations were denoted as mmol as the multiplication of water volume (liter) and appropriate ion concentration (Yurtseven et al 2014).

\section{Results and Discussion}

During the growing season, irrigation was done 8 times and the average salinity levels were 0.27 , $1.58,3.12,1.95$ and $3.45 \mathrm{dS} \mathrm{m}^{-1}$ for $\mathrm{S}_{1}, \mathrm{~S}_{2}, \mathrm{~S}_{3}, \mathrm{~S}_{4}$ and
$\mathrm{S}_{5}$ treatments, respectively. The $\mathrm{S}_{4}$ and $\mathrm{S}_{5}$ treatments had higher salinity than predicted. It was because the added salts had various solubilities and jips solved in a different manner than chloride salts. Anyway the differences of the water salinity levels than predicted weren't extremely high to effect the design of the experiment.

\subsection{Drainage water salinity}

Examined drainage water salinity resulted in $\mathrm{L}_{15}$ having salinity between $15.11 \mathrm{dS} \mathrm{m}^{-1}\left(\mathrm{~S}_{5}\right)$ and 17.84 $\mathrm{dS} \mathrm{m}^{-1}\left(\mathrm{~S}_{3}\right)$ and for $\mathrm{L}_{35}$ treatment having salinity between $12.81 \mathrm{dS} \mathrm{m}^{-1}\left(\mathrm{~S}_{1}\right)$ and $17.47 \mathrm{dS} \mathrm{m}^{-1}\left(\mathrm{~S}_{3}\right)$. The changes in drainage water salinity is statistically significant for both treatments irrigation water salinity and leaching fractions (Figure 1). Drainage water salinity has been highest $\left(17.84 \mathrm{dS} \mathrm{m}^{-1}\right)$ for treatment $\mathrm{S}_{3}$ which was containing the highest level of soluble salts. This value is approximately $17 \%$ higher than the average of other treatments. The reason behind this, is the fact that chloride salts are highly soluble and easily leachable (Yurtseven et al 2003). Though salinity level in $\mathrm{S}_{5}$ treatment was high and same as $\mathrm{S}_{3}, \mathrm{NaCl}+\mathrm{CaSO}_{4} \cdot 2 \mathrm{H}_{2} \mathrm{O}$ salt composition inhibited the effect of drainage water salinity and provided the salinity level similar to that $\mathrm{S}_{2}$ and $\mathrm{S}_{4}$ treatments which were low salty irrigation waters.

The leaching fraction affected the salinity of drainage water (Figure 1). The average drainage water salinity in $\mathrm{L}_{15}$ treatment was higher than $\mathrm{L}_{35}$ treatment of about $10 \%$. Lower level of leaching fractions resulted in average a more concentrated drainage water because of highly soluble salts. Since soil was sandy-loam and $15 \%$ of leaching fraction was enough to provide an efficiently leaching the profile, drainage water became more concentrated for treatments with lower leaching fractions (Oster \& Rhoades 1978; Yurtseven et al 2011).

\subsection{Salt load}

As salt load, salts that were added to soil columns with irrigation water and the salts that were collected from the profiles as leached water via drainage were evaluated. 

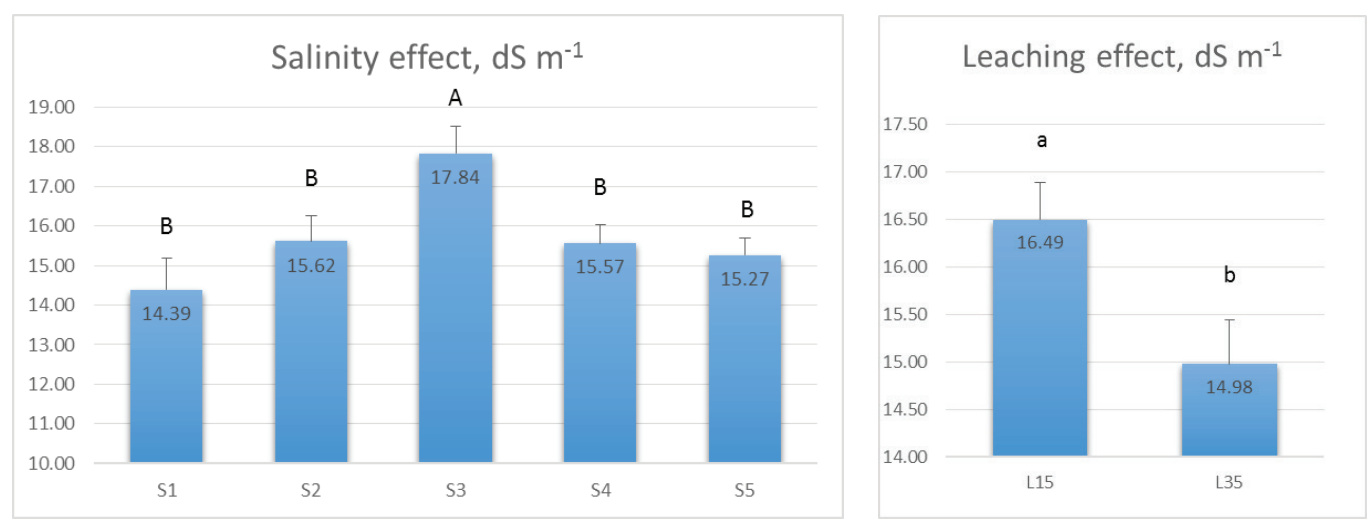

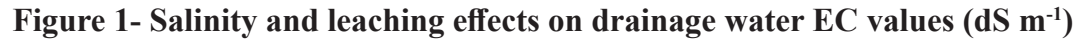

Salt load values varied between $2370 \mathrm{ECmm}$ $\left(\mathrm{S}_{1}\right)$ and $3918 \mathrm{ECmm}\left(\mathrm{S}_{3}\right)$ for $\mathrm{L}_{15}$, and between 5434 ECmm $\left(\mathrm{S}_{1}\right)$ and $6900 \mathrm{ECmm}\left(\mathrm{S}_{5}\right)$ for $\mathrm{L}_{35} . \mathrm{S}_{3}$ and $\mathrm{S}_{5}$ had higher irrigation water salinity $\left(3 \mathrm{dS} \mathrm{m}^{-1}\right)$ and caused the highest drainage water salt load. As previously explained, the $\mathrm{EC}$ values of drainage water from the $\mathrm{L}_{15}$ treatment had higher average drainage water salinity with lower leaching fraction. However, when looking at salt loads, $\mathrm{L}_{35}$ having a higher leaching fraction, had the highest salt load values, i.e. highest total salt leached from the profile occurred. Even having low salinity level of irrigation water, providing a higher volume of drainage water related with the high level of leaching, consequently resulted a higher level of salt loads (Figure 2). Increase in leaching fractions from $15 \%$ to $35 \%$ resulted in an average increase of $84 \%$ in salt load. Results are consistent with which were given in Yurtseven et al (2014).

While in drainage water only leaching fraction was significantly important, interaction was significantly important for irrigation water salt load.

When examining salt load values of irrigation water $(\mathrm{ECmm})$, the variation was between 281 for $\mathrm{S}_{1} \mathrm{~L}_{15}$ and 6367 for $\mathrm{S}_{5} \mathrm{~L}_{35}$ treatments. For all treatments except for $\mathrm{S}_{3} \mathrm{~L}_{15}$ and $\mathrm{S}_{5} \mathrm{~L}_{15}$ the total salt load leached with drainage was higher than loaded with irrigation water. The difference in salt load between irrigation water and drainage water was proportionally lower for treatments with higher salt and lower leaching fractions (Figure 3). Considering the total salt load,

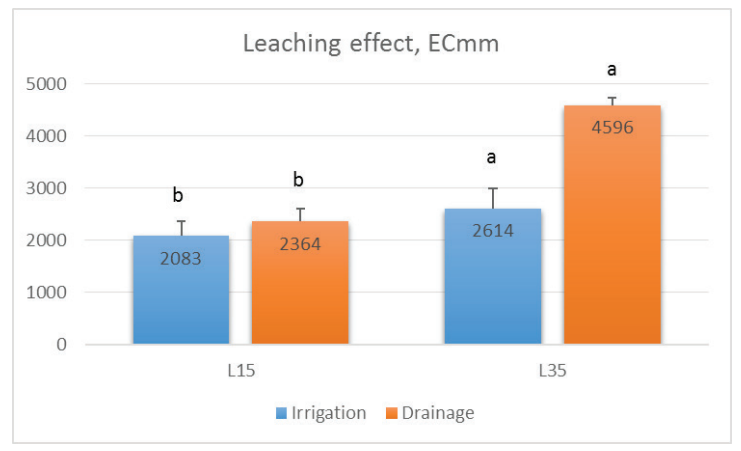

Figure 2- The effect of leaching fractions on drainage water salt load (ECmm)

leaching has been high in all treatments except $\mathrm{S}_{3}$ and $\mathrm{S}_{5}$. This proved that it is possible to obtain high enough leaching with irrigation water salinity till $1.5 \mathrm{dS} \mathrm{m}^{-1}$ salinity level. For high leaching at $3 \mathrm{dS}$ $\mathrm{m}^{-1}$ salinity level, $35 \%$ leaching fraction is needed. In general says, $15 \%$ leaching fraction is enough to able to leach salts from the soil and which are loaded with irrigation water as well (Ayers \& Westcott, 1988). In this study it has been seen that the low level of leaching fraction was quietly not enough for high salinity levels $\left(\mathrm{S}_{3}\right.$ and $\left.\mathrm{S}_{5}\right)$, but was noticeably enough for all of other treatments.

Salt load values were considered in concentration $\left(\mathrm{mmol}_{\mathrm{c}}\right)$ form for the salinity components as well. Therefore, highly active ion chloride and some of ions and components such as $\mathrm{Na}^{+}, \mathrm{Ca}^{+2}, \mathrm{Mg}^{+2}, \mathrm{SO}_{4}^{-2}$ and $\mathrm{CO}_{3}^{-2}$ were examined (Yurtseven et al 2014). 


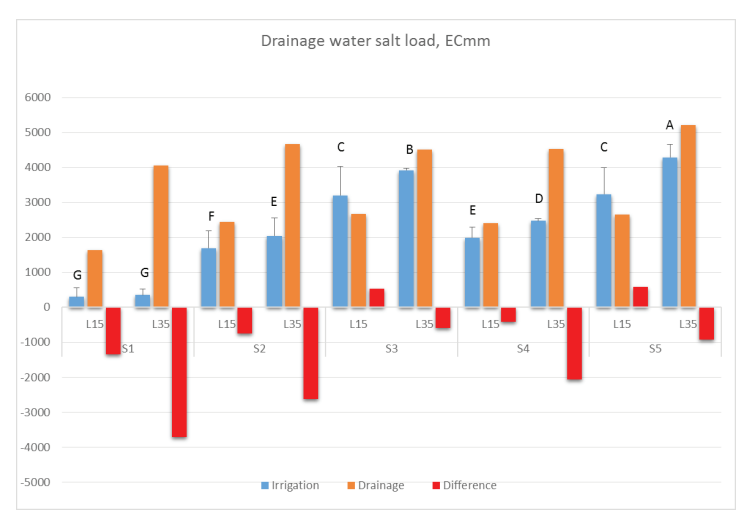

Figure 3- Changes in salt load (ECmm) values in drainage water in relation with irrigation water salinity and leaching

\subsubsection{Chloride load}

Figure 4 shows the interaction of chloride with the treatments. Leaching of chloride was insufficient and chloride has accumulated in all treatments. Chloride load by the irrigation water were greatly affected by the interaction between irrigation water salinity and leaching fractions (Yurtseven et al 2014). $S_{2}$ and $S_{3}$ treatments had the highest irrigation chloride levels because of the highest level of chloride salt addition (Heng et al 1991). These values were $1448 \mathrm{mmol}_{\mathrm{c}}$ for $\mathrm{S}_{2} \mathrm{~L}_{15}$ while 4170 $\mathrm{mmol}_{\mathrm{c}}$ for $\mathrm{S}_{3} \mathrm{~L}_{35}$. As a higher volume of water was applied to $\mathrm{L}_{35}$ treatments, they had a higher level of $\mathrm{Cl}^{-}$compared to $\mathrm{L}_{15}$ treatments. Drainage $\mathrm{Cl}^{-}$levels however, were affected by irrigation water salinity and leaching ratios individually (Figure 5).

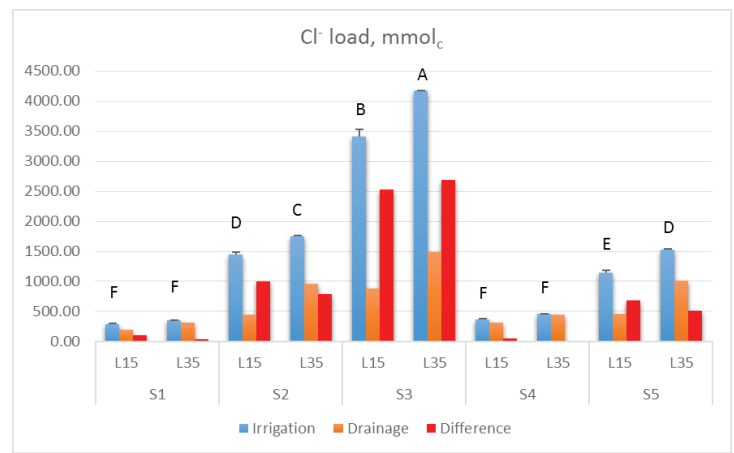

Figure 4- Chloride accumulation as mmol related to irrigation water salinity and leaching ratio

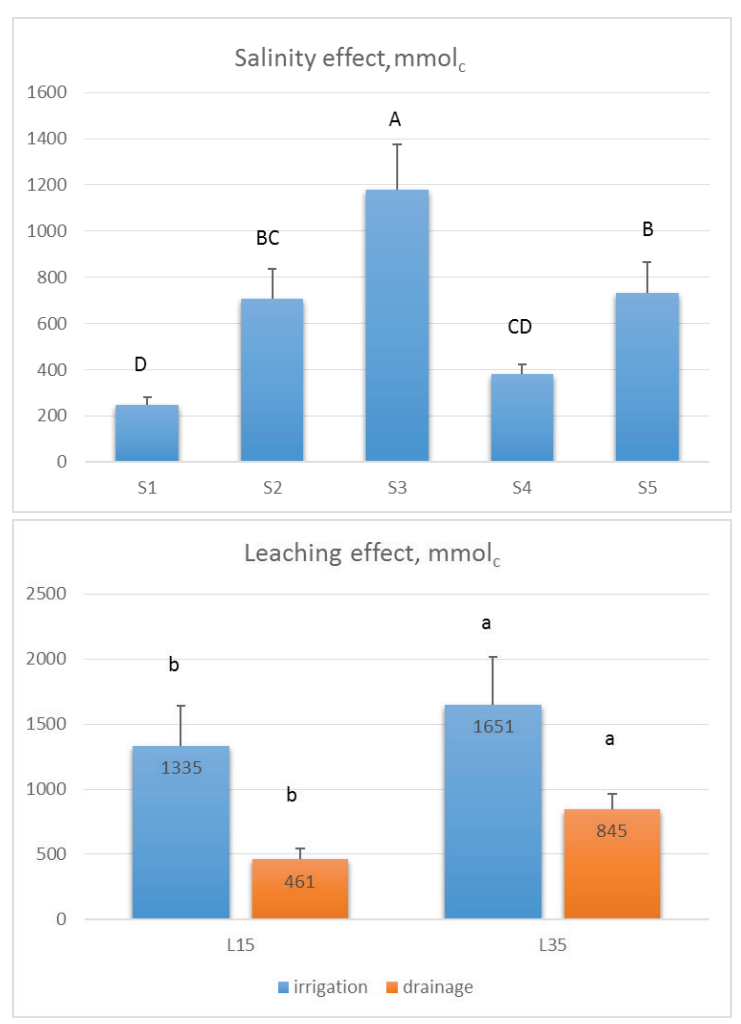

Figure 5- Salinity and leaching effects on drainage water $\mathrm{Cl}^{-}$load (mmol)

$\mathrm{S}_{3}$ treatment had the highest level of $\mathrm{Cl}^{-}$in drainage water $\left(1177 \mathrm{mmol}_{\mathrm{c}}\right)$ followed by $\mathrm{S}_{5}$ and $\mathrm{S}_{2}$ treatments. In other words, $\mathrm{S}_{3}$, which was loaded with highest level of $\mathrm{Cl}^{-}$by irrigation water, caused drainage water with the highest level of $\mathrm{Cl}^{-}$load as well. For the experimental conditions, add more $\mathrm{Cl}^{-}$, led to the highest level of leaching. $\mathrm{L}_{35}$, with the highest level of leaching fraction, had the highest leaching of $\mathrm{Cl}^{-}$. $\mathrm{Cl}^{-}$load levels of $\mathrm{L}_{15}$ and $\mathrm{L}_{35}$ treatments are 461 and $845 \mathrm{mmol}_{\mathrm{c}}$, respectively and the difference is at a level of $83 \%$. Chloride coming with irrigation is approximately 2.8 times the $\mathrm{Cl}^{-}$ load leached with drainage.

\subsubsection{Sulphate load}

Drainage water $\mathrm{SO}_{4}^{-2}$ load variations are shown in Figure 6. All treatments had a high level of $\mathrm{SO}_{4}^{-2}$ load leached from the profiles via drainage water. 
It can be said that $\mathrm{SO}_{4}^{-2}$ leaching was the case for all treatments (Yurtseven et al 2014). $\mathrm{S}_{1}, \mathrm{~S}_{2}$ and $\mathrm{S}_{3}$ treatments had higher leaching sulphate load rates. This is the result of the sulphate that originally have in the soil, and leached out from the soil with leaching water. In $\mathrm{S}_{4}$ and $\mathrm{S}_{5}$ because of the sulphate salt loading, the sulphate leached by the drainage water was relatively less or not leached at all $\left(\mathrm{S}_{5} \mathrm{~L}_{15}\right)$. That is, $\mathrm{SO}_{4}^{-2}$ loaded by irrigation water for $\mathrm{S}_{4}$ and $\mathrm{S}_{5}$ was high so at the end the total $\mathrm{SO}_{4}^{-2}$ leached (loaded with irrigation-leached with leaching fraction) became relatively small but, in fact the total sulphate leached from the soil were the highest.

There is an interaction effect on irrigation water sulphate loads. While salinity (S) has no effect on sulphate that was being leached with drainage water, leaching ratios were significantly important and $\mathrm{L}_{35}$ had higher sulphate load (Figure 6). As the leaching fraction increased from $15 \%$ to $35 \%$, the increase in the sulphate loads of the irrigation water were $15.7 \%$ while on the drainage water was $85.4 \%$. Leaching ratios for $\mathrm{L}_{15}$ and $\mathrm{L}_{35}$ treatments sulphate loads are 1177 and $2948 \mathrm{mmol}_{\mathrm{c}}$ respectively. In average for all treatments $\mathrm{SO}_{4}^{-2}$ leached with drainage were 2.7 times the $\mathrm{SO}_{4}^{-2}$ that came with irrigation.

\subsubsection{Alkalinity load}

As the soil profile alkalinity, $\mathrm{CO}_{3}^{-2}+\mathrm{HCO}_{3}^{-}$leaching was analyzed. It was seen that drainage masses were insufficient for the leaching of the alkalinity. When analyzing alkalinity leaching, the interaction between $\mathrm{CO}_{3}^{-2}+\mathrm{HCO}_{3}^{-}$load in irrigation treatments is important (Figure 7). Drainage water alkalinity load showed significant changes depending on leaching
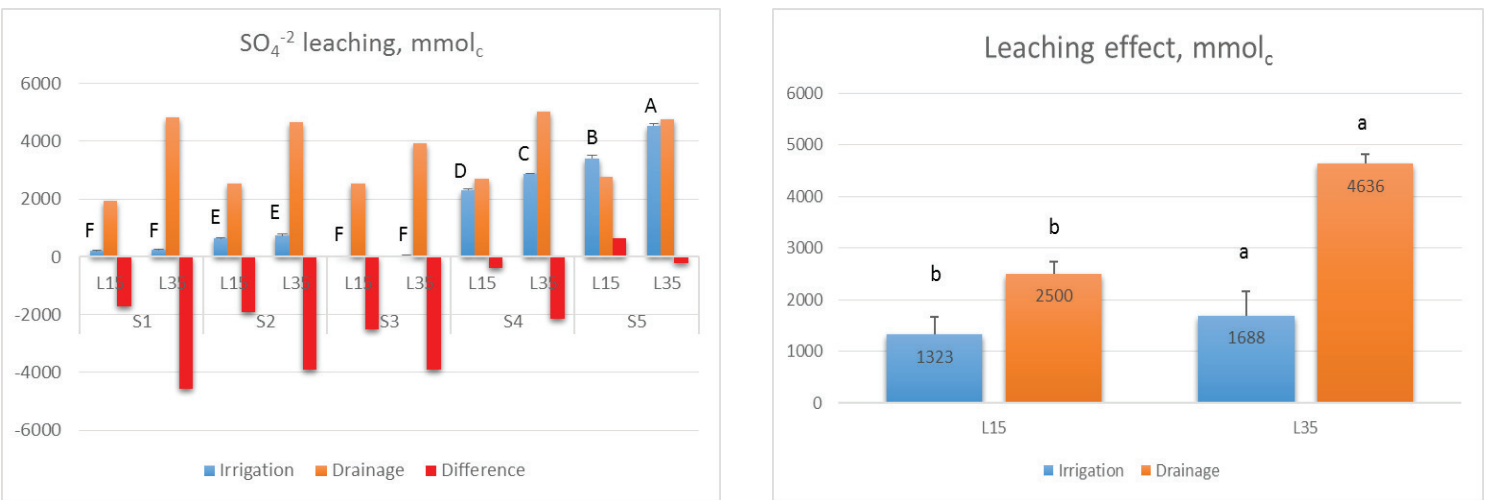

Figure 6- Sulphate leaching related to the irrigation water salinity and leaching ratio as mmol
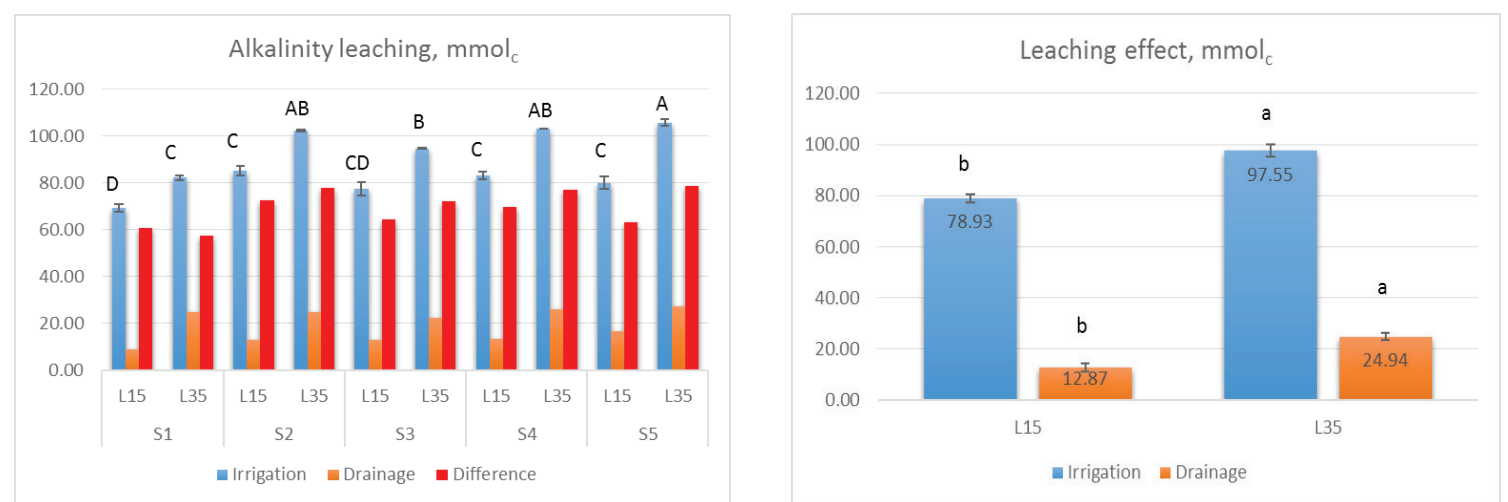

Figure 7- Irrigation and drainage water alkalinity variations related with treatments $\left(\mathrm{mmol}_{\mathrm{c}}\right)$ 
fraction in all treatments. Alkalinity that washed away was lower than the amount carried to the profiles with irrigation, and this result is compatible with Yurtseven et al (2014). Hence, there was alkalinity accumulation in the profiles. Naturally, a higher leaching ratio causes higher alkalinity and leaching. As leaching ratio increased from $15 \%$ to $35 \%$, alkalinity load increased $24 \%$ in irrigation water and $94 \%$ in drainage water. Accumulation in $\mathrm{L}_{15}$ and $\mathrm{L}_{35}$ treatments were respectively 66.1 and $72.6 \mathrm{mmol}_{\mathrm{c}}$ in average. $\mathrm{CO}_{3}^{-2}+$ $\mathrm{HCO}_{3}^{-}$added with irrigation were approximately 4.7 times to that leached away with drainage.

\subsubsection{Sodium load}

Sodium loads showed interaction in irrigation water, while in drainage water only leaching fractions effected significantly (Figure 8). As leaching ratio increased from $15 \%$ to $35 \%$, irrigation water $\mathrm{Na}^{+}$ load increased by $28 \%$, and drainage water $\mathrm{Na}^{+}$load increased by $78 \%$. In all treatments it has been seen that sodium leached out from the soil profile were higher than added with irrigation. Total leached out sodium were $825 \mathrm{mmol}_{\mathrm{c}}$ for $\mathrm{L}_{15}$, and $1713 \mathrm{mmol}_{\mathrm{c}}$ for $\mathrm{L}_{35} \mathrm{Na}^{+}$leached away with drainage water were approximately 3.3 times the total amount of loaded.

\subsection{5. $\mathrm{Ca}^{+2}$ load}

Calcium was one of the ion that were added to all irrigation waters except $\mathrm{S}_{1}$. It has been seen that $\mathrm{Ca}^{+2}$ accumulated in all treatments. The highest level $\mathrm{Ca}^{+2}$ loads were detected at $\mathrm{S}_{3}$ and $\mathrm{S}_{5}$ treatments for irrigation waters due to the adding $\mathrm{Ca}^{+2}$ at highest level. Interaction is statistically important for irrigation treatments (Figure 9). Small variations
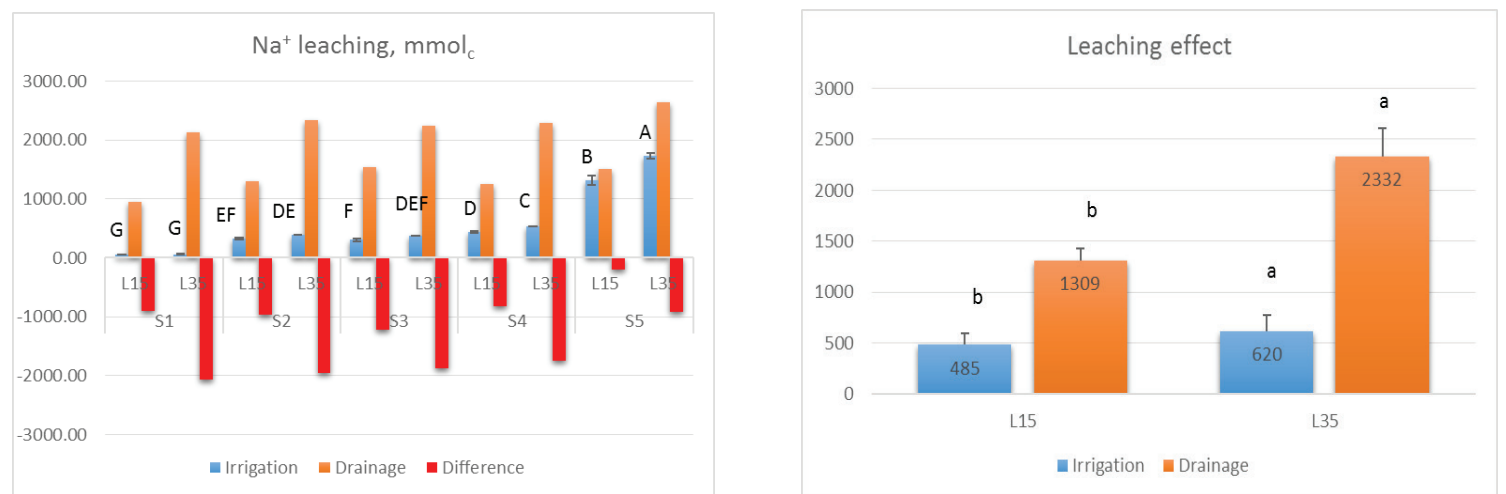

Figure 8- $\mathrm{Na}^{+}$load variation as $\mathrm{mmol}_{\mathrm{c}}$ of Irrigation and drainage water related with the treatments
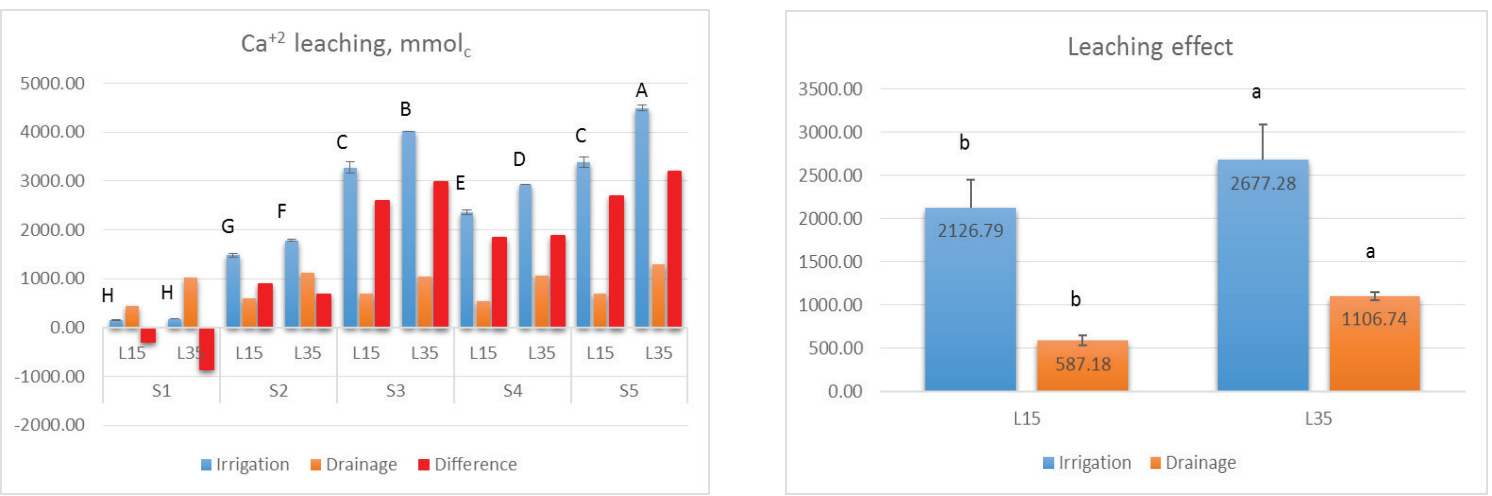

Figure 9- $\mathrm{Ca}^{+2}$ load variation of irrigation and drainage water as mmol related with the treatments 
were detected for leaching $\mathrm{Ca}^{+2}$ with the drainage water but higher at $\mathrm{L}_{35}$ level than $\mathrm{L}_{15}$ for leaching treatments and the difference is $88.4 \%$. However for the irrigation waters the same difference is $26 \%$. $\mathrm{Ca}^{+2}$ loads that were carried with water were approximately 2.8 times the total amount of $\mathrm{Ca}^{+2}$ leached away with drainage.

\subsection{6. $\mathrm{Mg}^{+2}$ load}

Since no extra $\mathrm{Mg}^{+2}$ were added to the soil with irrigation water, $\mathrm{Mg}^{+2}$ was the ion that washed away the most. In all treatments, level of leaching was higher than the level of initially added $\mathrm{Mg}^{+2}$ (Yurtseven et al 2014). While irrigation water $\mathrm{Mg}^{+2}$ loads showed interaction effect, leaching fractions showed an important effect on drainage water $\mathrm{Mg}^{+2}$ loads. For the leaching fractions in $\mathrm{L}_{35} \mathrm{Mg}^{+2}$ loads increased by $24.5 \%$ in irrigation, while $\mathrm{Mg}^{+2}$ leached away with drainage increased by $87 \%$ (Figure 10). $\mathrm{Mg}^{+2}$ leached away with drainage were approximately 18 times the initial $\mathrm{Mg}^{+2}$ carried by irrigation water.

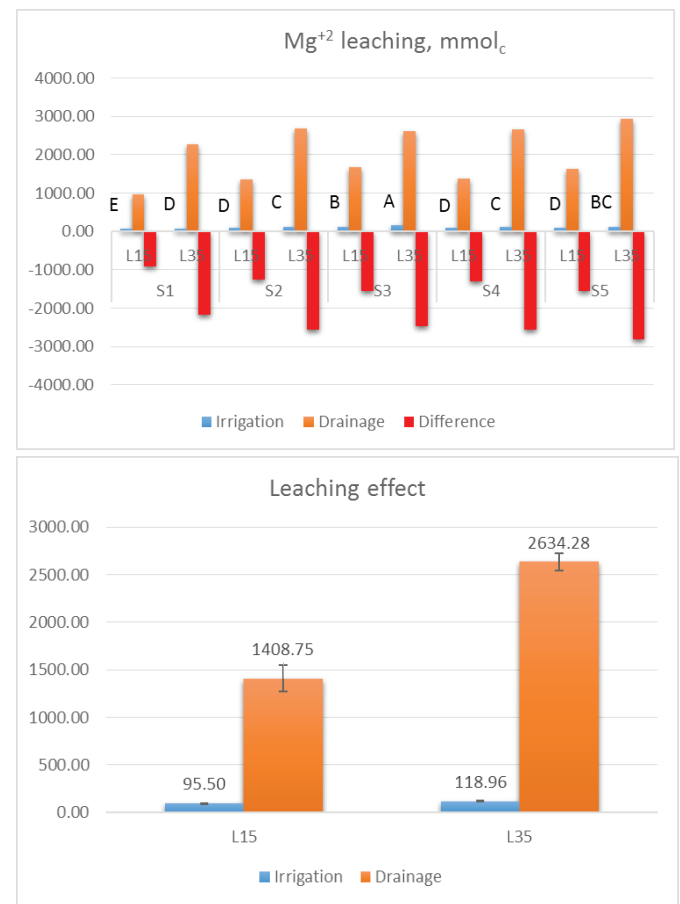

Figure 10- $\mathrm{Mg}^{+2}$ load variations as $\mathrm{mmol}_{\mathrm{c}}$ due to the experimental treatments

\section{Conclusions}

In this experimental conditions with SL soil, it can be said that drainage water became more saline with $15 \%$ of leaching fraction than with $35 \%$. It means that the salinity could be leached out easily, with this percentage $(15 \%)$ of leaching water, as Ayers $\&$ Westcot (1988) stated, under drip irrigation. It is concluded that, under effective leaching conditions, drainage water concentration can be increased due to the fact that leachable salts in the soil contributed easily to the leaching water. So drainage water became more concentrated, and drainage water salinity was concluded to be highest in treatment with most soluble salts added $\left(\mathrm{S}_{3}\right)$.

High level of chloride salts, i.e. $\mathrm{NaCl}$ and $\mathrm{CaCl}_{2}$, having a high solubility led to high levels of salinity $\left(\mathrm{S}_{3}\right)$ in drainage water. Gypsum $\left(\mathrm{S}_{4}, \mathrm{~S}_{5}\right)$ has limited effect to drainage water salinity.

When it is considered the salt load; in almost all treatments drainage water salt load was high and was not affected by salinity treatments but rather by the increase in leaching fraction. The higher the leaching fraction caused the higher the drainage water salt load. The salt leached from the lyzimeters at almost the same for the treatments, varying with the leaching fractions. Although no salt were added to the $S_{1}$ treatment, it has seen that the most salt leached from the soil of $S_{1}$. This is because of the effects of added salt to the other treatments. Added salts caused that relatively the less leaching has been occured. Consequently more salt were leached with the higher level of leaching fraction.

Since chloride is easily move in the soil with water, more $\mathrm{Cl}^{-}$added treatments in irrigation water caused more concentrated drainage water. Also increasing leaching ratio caused to increase drainage water $\mathrm{Cl}^{-}$load.

Sulphate, leached to all treatments and leaching $\mathrm{SO}_{4}^{-2}$ increased with increasing leaching fraction. However, since sulphate has limited solubility and motion with water, there was no difference in drainage water between various salinity levels as it was for chloride. 
Alkalinity $\left(\mathrm{CO}_{3}^{-2}+\mathrm{HCO}_{3}^{-}\right)$values lead to accumulation in the profiles under the effect of leaching fractions.

The analysis of $\mathrm{Na}^{+}, \mathrm{Ca}^{+2}$ and $\mathrm{Mg}^{+2}$ loads concluded that while $\mathrm{Na}^{+}$and $\mathrm{Mg}^{+2}$ showed leaching, $\mathrm{Ca}^{+2}$ showed accumulation. All three ions concluded in increased total leached ion levels due to the increase in leaching fractions.

\section{Acknowledgements}

This study has been supported by TUBİTAK (The Scientific and Technological Research Council of Turkey) (TOVAG 114O554)

\section{References}

Anonymous (1993). The determination of inorganic anions in water by ion chromatography; Method 300.0. U.S. Environmental Protection Agency, Cincinnati, Ohio

Ayars J E, Christen E W \& Hornbuckle J W (2006). Controlled drainage for improved water management in arid regions irrigated agriculture. Agricultural Water Management 86: 128-139

Ayers R S \& Westcot D W (1988). Water quality for agriculture. FAO Irrigation and Drainage Paper 29, Rome

Bond W J (1998). Soil physical methods for estimating recharge. In: L Zhang \& $\mathrm{G} \mathrm{R}$ Walker (Eds.), The Basics of Recharge and Discharge 3, CSIRO, Melbourne, pp. 17-20

Çiftçi N, Kara M, Yılmaz M \& Uğurlu N (1995). Konya Ovasında drenaj suları ile sulanan arazilerde tuzluluk ve sodyumluluk sorunları. 5. Ulusal Kültürteknik Kongresi Bildirileri, 30 Mart-2 Nisan, Antalya, s. 471-481

Heng L K, White R E, Bolan N S \& Scotter D R (1991). Leaching losses of major nutrients from a moledrained soil under pasture. New Zealand Journal of Agricultural Research 34: 325-334

Northey J E, Christen E W, Ayars J E \& Jankowski J (2006). Occurrence and measurement of salinity stratification in shallow ground water in the Murrumbidgee Irrigation Area, South-Eastern. Agricultural Water Management 81(1-2): 23-40

Oster J D \& Rhoades J D (1978). Calculated drainage water compositions and salt burdens resulting from irrigation with river waters in the Western United
States. Journal of Environmental Quality 4: 73-79, Australia

Rhoades J D (1983). Using saline waters for irrigation, In: H S Mann (Ed), Proc. of International Workshop on Salt Affected Soils of Latin America, Maracas, Venezuela, Oct 23-30, 1983, pp. 22-52

Şener S (1993). Ege Bölgesinde lizimetre koşullarında değişik kalitedeki sulama sularının pamuk verimine ve toprak tuz dengesine etkileri. Köy Hizmetleri Menemen Araştırma Enstitüsü Müdürlüğ̈̈ Yayınları, No: 192, Menemen

USSL (1954). Diagnosis and improvement of saline and alkali soils. (Ed: L A Richards) US Salinity Lab. Agricultural Handbook No: 60

Walker G R, Zhang L, Ellis T W, Hatton T J \& Petheram C (2002). Estimating impacts of changed land use on recharge: Review of modelling and other approaches appropriate for management of dry land salinity. Hydrogeology Journal 10(1): 68-90

Wolters W \& Bos M G (1990). Interrelationship between irrigation efficiency and the reuse of drainage water. Symposium on Land Drainage for Salinity Control in Arid and Semi-arid Regions, 25 February-2 March 1990 Drainage Research Institute, Cairo, Egypt, pp. 237-245

van Hoorn J W \& van Alpen J G (1988). Salinity control, salt balance and leaching requirement of irrigated soils. (Lecture notes), ICAMAS Istituto Agronomico Mediterraneo di Bari, Italy

Yurtseven E, Kesmez G D \& Ünlükara A (2003). The effects of potassium on salinity tolerance, fruit quality and water consumption for tomato (lycopersicon esculentum) under saline conditions. International Workshop on Sustainable Strategies for Irrigation in Salt-prone Mediterranean Regions: a System Approach, Cairo, Egypt, December 8-10, 2003. Centre for Ecology and Hydrology, Wallingford, UK. Proceedings of an International Workshop, pp. 192-203

Yurtseven E, Altınok S, Öztürk H S \& Selenay M F (2011). Lizimetre koşullarında farklı sulama yönetimi pratiklerinin drenaj suyu hacmi ile kalitesine, toprak tuzluluğuna ve yoncada (Medicago sativa) verim ve su kullanım özelliklerine etkisi. TUBITAK-TOVAG 1001 Proje Sonuç Raporu (Proje No: 1090165), Ankara, 147 s

Yurtseven E, Öztürk H S \& Avc1 S (2014). Mass balance criteria in soil salinity management: Different irrigation water qualities and leaching ratio. Journal of Agricultural Sciences, 20: 103-111 